УДК: 7.033

ББК: 85.13

DOI: $10.18688 / \mathrm{aa} 2111-02-19$

L. Sh. Mikayelyan

\title{
Various Aspects of the Image of a Dragon-serpent in Armenian and South-Caucasian Sculpture of the $7^{\text {th }}-14^{\text {th }}$ Centuries ${ }^{1}$
}

\section{Introduction}

The image of a dragon is one of the universal archetypes of world culture and, at the same time, the most multifaceted in its artistic manifestations and symbolism. If one gives a very generalized definition of its functions in Indo-European mythology including ancient Armenian, then dragon personified the primordial chaos and chthonic forces, whereas fighting the dragon was the leading theme of the victory of a cultural hero over evil and disorder and the act of consecration of a hero, the transition to another level, overcoming death. In many cultures, the snake was primarily associated with the earth and water elements and the underworld. At the same time, in the ancient cosmogonic concepts of many peoples, the body of the celestial serpent-dragon (ouroboros) was thought as the boundary of the inhabited macrocosm. According to astrological notions, its head and tail cause solar and lunar eclipses, as well as determine the change of day and night [14].

Due to their liminal position between the inferior and upper worlds, the dragon and serpent were associated with fertility and rebirth, and were also endowed with apotropaic functions, that is, they initially had explicit bipolar symbolism [12]. With the advent of Christianity, along with the rejection of pagan notions and cults, especially in the early Middle Ages, the dragon retained mainly its destructive hypostasis becoming a symbol of the devil and hell. Only on the turn of the $9^{\text {th }}-10^{\text {th }}$ centuries in the Armenian and South-Caucasian art, we find a certain appeal to the archaic, positive functions of this monster, which was especially expressed in the monuments of the $12^{\text {th }}-14^{\text {th }}$ centuries.

The centuries-old veneration of the dragon-serpent in Armenia had its own local manifestations. It was called प.hrmu (vishap), which meant a monster, an enormous snake, especially a water one. The word was also used in the meaning - huge, gigantic. At the same time, vishap is the traditional name for unique megalithic stelae in the Armenian Highlands of the $3^{\text {rd }}-2^{\text {nd }}$ millennium BC. Most of them are hewn in the fish shape and bear images of the bull's head and skin as the evidence of ritual sacrifices. The latter were placed vertically in high mountains, at sacred precincts, and were associated with the veneration of springs and reservoirs ${ }^{2}$. The dragon image is also reflected in Armenian toponyms and natural phenomena: the Lake Van

The research was done within the framework of a grant for the project: "Sculpture Decoration of Ruined and Less Studied Church Complexes of the $12^{\text {th }}-14^{\text {th }}$ centuries in Armenia" (21T-6E291), provided by the Science Committee of the Ministry of Education, Science, Culture and Sports RA.

2 For detailed account on the ancient Armenian stelae-vishaps, see [1]. 
in historical Armenia was called the Dragon Lake, and the dragon was often identified with hurricane and thunderstorm [10, pp.77-84].

In the medieval Armenian art, we know a number of dragon-snake images, fairly ambiguous in their symbolism, many of which have not been properly studied or interpreted. It particularly concerns the examples beyond the traditional Christian understanding of dragon as the embodiment of evil. The purpose of this paper is to reveal, as far as possible, the content of these extra-canonical images based on the general compositional context and iconographic features, taking into consideration their analogies in neighboring cultures - primarily Islamic samples, as well as drawing on ethnographic material and medieval written sources.

The images of dragons and serpents are examined together, since they are often interchangeable, but at the same time - in order to determine more specifically their differences. For instance, one distinguishes a dragon from a snake primarily by the position of its head to the body and the presence of protruding ears, as well as large sizes. Other details in the depictions of dragons such as wings, forelegs, etc. are more visual and do not need to be specified. The next task is to differentiate the dragon from the images of some fantastic creatures similar to him iconographically and symbolically, such as sea monsters in the story of Jonah, the image of the Iranian "senmurv" or the images of sphinxes and lions with dragon tails.

In Christian iconography, the dragon acts as a symbol of evil, Satan (mainly in the scenes of the Fall, the Baptism of Christ, the Descent into Hell, and in compositions with holy warriors). The earliest images of dragon-serpent in the Armenian medieval sculpture have been known from the canonical scenes of dragon-slaying saints. These are the reliefs of the $6^{\text {th }}-7^{\text {th }}$-centuries stelae from Armenian settlements of the historical Gugark (the south of present-day Georgia,

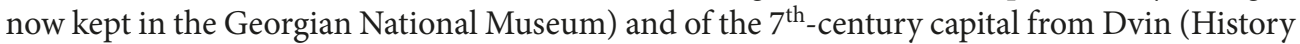
Museum of Armenia) preserved in a damaged state. On one of the segments of the large stela from Brdadzor, the Holy Warrior strikes a huge, twisted snake with a spear. The capital of Dvin carries a relief with two holy riders flanking the Cross with a bust of Christ, and under the hooves of their horses, round heads of snakes are carved [17, pp. 211-214]. On the second small stela from Brdadzor, the looped body of the serpent has a beast head with ears, on which even a bleeding wound is visible. On the stela of Khojorni the similar rider kills a large spotted snake, in this case with a serpent head [11, pp.40-45].

The next depiction of a saint killing a snake in Armenian art is found on the north façade of the Church of the Holy Cross on the Aghtamar Island (915-921). Among the three mounted warriors: St. George, St. Sergios (Sarkis) and St. Theodore, the latter was carved as a dragon-slayer [4, pp. 19, 24, fig. 50]. The same compositions appear in Georgian art of the post-Arab period, in the decoration of the cathedrals in Martvili ( $10^{\text {th }}$ century), in Nikortsminda (10101014), etc. On the above examples, the symbolism and iconography of the dragon-snake has been well studied. Here, I would like to emphasize the iconographic detail of the Aghtamar relief - the heart-shaped knot on the snake body, which becomes typical for the iconography of a number of Armenian and Islamic dragons. On the later Armenian miniatures of the Baptism of Christ, we usually find a serpent in the waters of Jordan, often with the same knots on the body (for example, the Gospels of 1305, Matenadaran, No. 2744, fol. 4a), which could mean it was tied, that is defeated, according to the Psalms (Psalm 73: 13-14). 
There are two more remarkable serpent images in the decoration of the Church of the Holy Cross, on the scenes of the Fall. At the northern façade of the church, a Tree is carved with a snake coiled along it and the figure of Eve leaned towards the tempter [4, pp. 19, 24, fig. 48]. The snake has four legs, which reflects the apocrypha's texts, for example "The Book of Adam" and others known in Armenian translations. According to them, before the curse of God the snake had limbs, even wings, and ability to speak. On the drum fresco of the church, in the cycle of Creation the dragon-like creature is painted in the same tradition: with four legs, a long dog head and wings [16, pp. 249-251]. Here the snake notably reminds the iconography of the socalled "senmurv" - the Iranian good being, the embodiment of Farn, well known in Eastern Christian art. Most likely, the artist thereby wanted to clearer emphasize the nobility of the serpent before the Fall. The fact that the image of "senmurv" was well known to the masters of Aghtamar can be seen from the rendering of the sea monster in the scene of the Prophet Jonah of the south façade of the church. Here, it is presented in the iconography of "senmurv" with only one difference: instead of a peacock tail it has a fish one. All this can indirectly testify to the benignant symbolism of Ketos on the Church of the Holy Cross [19].

In the early Christian and Byzantine tradition, as well as on the South-Caucasian monuments of the $10^{\text {th }}-12^{\text {th }}$ centuries, in the scenes of the prophet Jonah, the whale was usually depicted in the guise of fantastic sea monster, ascending to the sea monsters of the ancient world, more precisely the ketos. The latter in Greco-Roman culture were the mounts animals of the sea gods, and were also considered psychopomps [23, pp. 133-134, fig. 5-7]. In the Christian tradition, the whale swallows Jonah and releases him on the third day, which became an allegory of the death and resurrection of Christ. This symbolism undoubtedly goes back to the ancient archetype of sea monsters and dragons - boundary creatures, intermediaries between the worlds. It is noteworthy that in the Jewish exegesis: in Haggadah and Pseudo Philo of Alexandria, the image of Ketos has a clearly positive interpretation, inherited from the Greco-Roman tradition. The latter is presented as the savior of the prophet, in whose womb Jonah travels to the depths of the sea and other worlds [18]. However, in the Christian canon the functions of Jonah's whale are narrowed and differentiated: it becomes a symbol of decease, nothingness, just like the dragon - the embodiment of Satan and hell.

Nevertheless, the artistic tradition does not always follow the religious canon, and the fantastic creatures in Christian art were closely associated with ancient archetypes and were distinguished by freer interpretation. Taking into consideration the close symbolism of dragons and sea monsters in ancient mythologies, we understand their iconographic similarity, in particular in the scenes of Jonah. The finest example can be the Jonah's whale image treated as a dragon on the relief of the $10^{\text {th }}$ century from Kvaisa-Jvari (Fig. 1) [2, p.111, fig. 212]. Here a two-headed coiled monster is depicted with a reptile's tail (!), one head of which is swallowing the prophet, and the other is spewing him. On the same scene of the $10^{\text {th }}$-century relief from the Dranda Cathedral (Abkhazia), in the jaws of two fish-like beings with paws and wings, we see Jona's forepart and legs [5, pp. 262-267]. Here the creature is very close to the Early Christian Ketos. Thus, the main difference between the sea monsters and dragons is the presence of a fin instead of a serpentine tail.

The first examples of so-called non-canonical images of snake appear in the Church of Peter and Paul (895-906) at the Tatev monastery. Two niches of its east façade are decorated with 


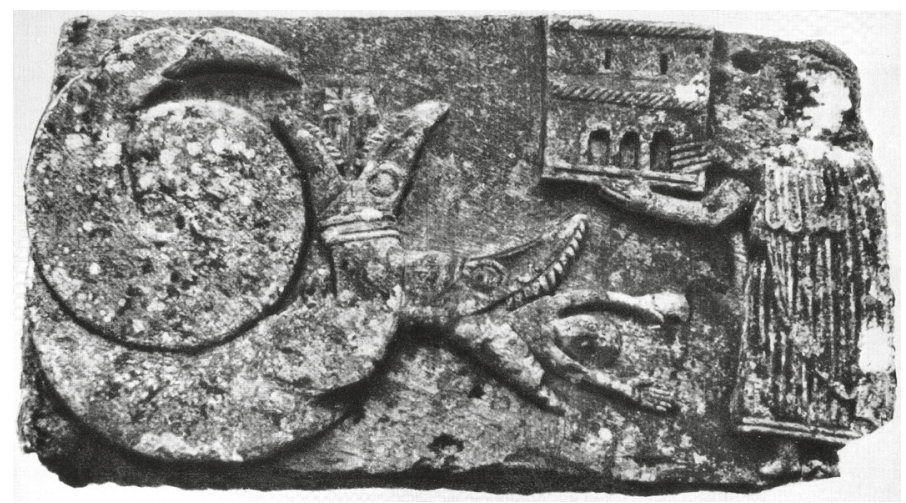

Fig. 1. Prophet Jonah and the whale. Relief of the Kvaisa-Jvari church (now lost), South Ossetia. $10^{\text {th }}$ century. After: Dadiani T. et al., 2017 [2, fig. 212]

large archivolts, along which we see paired confronted snakes. In between of them, two generalized, rather female faces emerge with curls, and above the north one, there is a fine rosette (Ill. 21). The snake heads with open mouths, where the teeth and long tongues are visible, are closely adjoined to the faces. Another pair of snakes is depicted on the lintel of the north window of the church, but here in the center is a male face with a diadem (?). The next similar composition of Tatev is on the window's edge of the west façade, but the relief is damaged and hidden behind a belfry of the $19^{\text {th }}$ century, so it is difficult to examine it now. Another face, but without snakes, is placed above the south window of the church.

The interpretation of these reliefs is still debatable. S. Mnatsakanyan considered the faces as images of patrons - the members of the princely family of Syunik. His hypothesis is still dominating in scientific milieu, but it was rightly criticized by Z. Hakobyan [8, p. 265]. S. Mnatsakanyan saw the portraits of the prince Ashot and his wife Shushanik in two completely identical, in our opinion female, or at least indefinite faces of the east façade. Moreover, based on the presence of a large rosette above the north one, he supposed that this is the image of Ashot [20, pp.14-16]. Even if we consider the possibility of depicting a patron on the Tatev church, it could rather be the male face of the north lintel, rendered in different style and endowed with some portrait features. Most likely, here is the image of ideal ruler, possibly compared with the luminary, and the snakes facing him should be interpreted as apotropaia [20, p. 17]. Their protective function is also confirmed by the ancient symbolism of heraldic compositions, where mirror images facing the central object denoted its sacredness and were interpreted as guardians.

Snakes flanking a human figure and a head are also presented at the Church of Holy Apostles (930-943) in Kars. In one case, they appear on the church drum, flanking one of the twelve very schematic human figures closely snuggled to his ears. Two other serpents confronting a human face are carved above the northwestern window, similar to the composition of the Tatev church. It is difficult yet to determine the meaning of these twelve figures of Kars presented in different poses, including the praying ones, except as allegorical images. They do not correspond at all to the iconography of the Apostles, as it was believed before, and they are not 
typical for the donors images neither, as it was suggested by S. Mnatsakanyan [20, pp.66-67]. However, the serpentine images of the Kars church, similar and contemporary with those of Tatev, should be considered as apotropaic.

Snakes dwell in many regions of Armenia representing a real danger to humans, but at the same time, there is numerous evidence of veneration of the snake as a bringing abundance guardian of a house. It was expressed both in the real feeding of the "domestic" snake and in the taboo of its killing, as well as in depicting of snakes on the columns and windows of dwellings. Snakes were widely used in folk magic and medicine; for example, the shed skin of a snake was considered a talisman against a snakebite (beliefs that have survived to this day) [12, pp. 191, 197]. Similar notions are largely attested among the peoples of the Near East, in Islamic sources. Thus, snakes were considered genius loci, guardians of shrines, and snake venom has been used against snakebites since ancient times [3, pp. 189-194]. The same archaic ideas are contained in the biblical story of the staff of Moses turning into a serpent and especially in the bronze snake he created, looking at which the people were cured of snakebites during the Exodus (Numbers 21: 6-9).

Let us return to the faces with snakes on the east façade of the Tatev church. Based on their identical, generalized execution, we can assume they were allegories of the sun and the moon. Each of them is flanked by two snakes with open mouths both threatening and defending the luminaries, which presented the idea of cyclical nature of time. The similar solar symbolism we can suggest in the composition on the window platband of the Kars church. The depictions of faces as allegories of the sun and the moon are well known in Armenian art of the later period. This is, for example, a round face in the center of the sundial on the south façade of the church in Goshavank ( $13^{\text {th }}$ century), from which fan-shaped rays radiate. On the upper part of a number of Armenian khachkars, we see round schematic faces with the same meaning [22, pp. 188190, fig. 313, 368, 483], they are also found in Armenian miniatures of the $12^{\text {th }}-15^{\text {th }}$ centuries, sometimes between two dragon heads [13, fig. 123]. Various rosettes in the church decoration also had solar symbolism, and they are often depicted next to sundials, as on the Church of St. Stepanos at the Haghartsin monastery (1244). At the east façade of the Tatev church, we find a rosette only above the north face, which is presumably the allegory of the sun, and two rosettes crown the lintel of the north window with the male face and snakes.

In ancient Armenian mythology, a snake was thought to enclose the celestial sphere, bordering the sky from the earth. It is attested to on the cult clay slabs of the $6^{\text {th }}-5^{\text {rd }}$ centuries BC from Dvin (History Museum of Armenia) [7, pp.119-121], where the horizontal figure of a snake in the middle separates the divine and earthly worlds. In addition, it was believed to determine the cycles of the sun and the moon by swallowing and spewing them. A vivid example of these ideas, widespread in Georgia as well, can be seen on the relief of the east pediment of the church in Pavnisi of the $10^{\text {th }}$ century. Here we see a dragon (a snake with ears) snuggling with its gaping jaws to a round disc - an image of a celestial body, most likely the sun [2, p. 118, fig. 304].

Many compositions with dragons, including those flanking human faces (or figures), are known in the monuments of Western Asia of the $12^{\text {th }}-13^{\text {th }}$ centuries. The dragon-serpent image is comprehensively presented in Islamic exegesis, literary sources, as well as scientific treatises, and it has been well studied over the past decades [3; 13]. Its connection with luminaries, 
with the ruler cult and especially its apotropaic functions has direct parallels with the archaic notions of Armenian culture reflected in the medieval art. On the other hand, after the Seljuk conquests, from the end of the $12^{\text {th }}$ century, of the entire region of Western Asia and Armenia, rather unified cultural environment developed, which led to the emergence of universal and stable artistic images. These factors explain the close iconographic and stylistic similarities of Islamic and Armenian dragons, as well as other fantastic creatures of the $12^{\text {th }}-14^{\text {th }}$ centuries.

Armenian medieval written sources also contain certain information about the perception of dragon images, mostly represented as the allegory of evil and destructive forces. The $5^{\text {th }}$-century historian Movses Khorenatsi conveys some of the Armenian folk legends mixed with historical narratives. In these episodes the dragon acts as a chthonic creature, and unrighteous semi-legendary or historical characters or groups of people hostile to the Armenian rulers are often associated with devilish forces identified with dragons [25, pp.117-118, 124-125, 187, 201]. P'avstos Buzand ( $5^{\text {th }}$ century) has a remarkable passage in which the Armenian king Pap Arshakid (370-374), who was disliked by the clergy because of his anti-church reforms, is represented possessed by demons, which twisted themselves around him in the form of white snakes [6, pp. 165, 202-203]. The $5^{\text {th }}$-century historian Yeghishe in his book about the war against Sasanian Iran repeatedly compares the enemy commander with a roaring dragon. In the same way, Tovma Artsruni (late $9^{\text {th }}$ century) represents the cruel Arab general Bugha in the image of a formidable and insatiable dragon, etc. [24, pp. 48-49, 193, 231-233]. Similar narratives are also preserved in Armenian fairy tales and in the epic David of Sasun [9, pp. 116-134] ${ }^{3}$.

However, at the beginning of the $10^{\text {th }}$ century, the Anonymous Continuator of Tovma Artsruni uses the image of a dragon to convey the heroic potency of the Artsruni princes comparing them to dragons. In the chapter dedicated to the godly king Gagik Artsruni (904/8-943), the author writes that he always stood guard over his kingdom like a sleeping dragon [24, pp.329, $340,367]$. In fact, we see that in the History of the House of Artsruni, written consistently by two authors, the dragon image acts both as an epithet of a formidable enemy and as an epithet of a powerful king - the defender of his people and boundaries. This literary allegory expressing the good, apotropaic hypostasis of the dragon-serpent was also reflected in the sculpture of the $10^{\text {th }}$ century, and then it becomes more pronounced in the art of the $13^{\text {th }}-14^{\text {th }}$ centuries.

The dragon-serpent images are found in abundance in both monumental and applied art of the Near East. In most cases, they are represented in a heraldic pair, flanking the arches of city gates or caravanserais, as well as decorating the façades of mausoleums and madrasahs. Above the two niches on the both sides of the main entrance of the Susuz-Han caravanserai (1246, Bucak, Turkey), two winged dragons are carved confronting to each other with open mouths, and in between there is a human face - the allegory of luminary [21; 14, pp. 87-91, fig. 7-10]. On the "Gate of the Serpents" of the citadel in Aleppo (1209-1210), we find two intertwined double-headed dragons (their tails also end with heads). With their necks they wrap around two rosettes in the form of an eight-pointed star - the symbol of an astral body. Double-headed winged dragons with heart-shaped knots and wide-open jaws were depicted above the entrance of the Fortress of Konya (1220, Ince Minareli museum) [3, pp. 83-90].

3 Similar traditions existed in pre-Islamic Iran, reflected in the epic Shah-name as well. In Zoroastrian beliefs the negative essence of dragons and snakes was especially pronounced, as they had been thought the creations of Ahriman - the evil spirit [3, pp.36-38]. 
From the point of view of symbolic, iconographic, and stylistic parallels with Armenian samples, the reliefs of the Syrian Monastery Mār Behnām of the $13^{\text {th }}$ century are very interesting (Mosul, Iraq). The decoration of portals of the complex contains a number of different compositions with dragons or with dragonhead motives. On the south outer portal, we see two winged knotted dragons facing with open jaws to the bowls. A lioness head is carved above the portal, and two figures of lionesses are at the corners, the left one of which has a dragon-tail - a popular artistic motif, to which we will return later. On the lintel of the same door, two birds in mirror image are depicted with dragon-tails as well. The similar dragon heads are used in the decor of the Cross base in the center of the lintel. The inner entrance to the baptistery chapel of Mār Behnām is framed by fourteen paired dragon heads. In the center of this upper belt, a lioness head is protruded [13, pp.32-34, 234-235; fig. 17-18, 50, 77, 198]. The latter like other lion images at the entrances is connected with solar symbolism quite understandable in the composition with dragons [3, pp.159-165]. And finally, above the portal of St. Behnam tomb, one can see the image of St. George killing a dragon.

The last single dragon, in this case embodying evil forces, is interpreted similarly to other paired samples: the same gaping mouth with a protruding tongue and ears and a heart-shaped knot on the body. This iconography becomes common for the images of a dragon both in the Islamic and Christian world; both for the depictions with a negative meaning of the image and with positive symbolism. In this well-established iconography the magnificent heraldic dragons on the portal lintel of the Vanstan monastery (1212-1227) designed to protect the shrine from evil were rendered (Fig. 2). They have gaping jaws with backward-curled lips, forked tongues, and protruding ears, while their bodies are covered with scales and tied in characteristic knots. Of note are the collars on the dragons' necks, which are also found on a number of Islamic dragons (at the gate in Aleppo; on the façade of the Çifte Minare madrasa, Erzurum; on a relief from the İnce Minare museum) [13, fig. 3b, 43, 154].

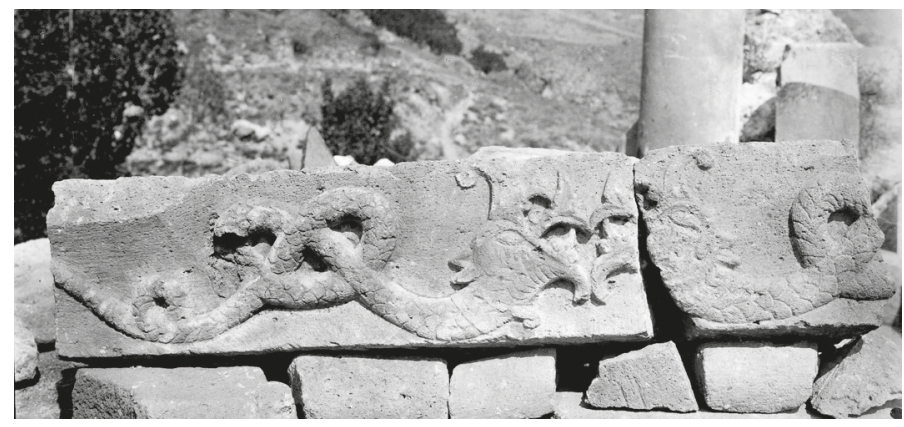

Fig. 2. Dragons. Lintel (now lost). Vanstan monastery, Armenia. 1212-1227. Photo: archive of A. Kalantar, provided by Research on Armenian Architecture

In all of the above examples, the dragons are presented with intertwined, knotted bodies, which had a certain symbolism going back to the ancient magical notions and practices of fixing the desired action through tying and weaving [13, pp. 159-168]. This etymology is evidenced by the decoration of the wall-column in the library (1063) of the Sanahin monastery. 
Here, two serpents as a roller grasp the base of the three-part capital and then intertwine on its central part, where their gaping mouths are clearly visible [15, p. 55]. The lateral parts of the capital are covered with braided ornament, echoing the central snake motif. The trunk and the base of the column are also decorated by twisted bands. On the same central segment of the other column of the library, a cross is carved in a wicker frame. The apotropaic meaning of the cross is well known, which indicates the equivalent meaning of these two images. Let us emphasize that the Sanahin library was built as a repository of not only manuscripts, but also the relics and treasures of the monastery.

Rather different compositions of dragon-snakes with the similar apotropaic meaning are known in the architecture of the medieval capital of Ani. Two north towers of the city fortress wall are encircled by two snake-cords with beast heads, which flank the bas-reliefs of bull heads [15, p. 57]. On the squinch of the south façade of the Church of St. Gregory in Ani (1215), paired dragons with paws and twisted tails are carved (Ill. 22), which have been many times compared with the relief in the niche of the $13^{\text {th }}$-century Emil Saltuq tomb in Erzurum. On the spandrels of the portal arch of the South Caravanserai in Ani, the images of lionesses and knotted snakes were depicted [13, fig. 10-11, 8]. Intertwined confronting dragons with looped tails crowned the entrance to the fortress in Arinj as its guardians ( $15^{\text {th }}$ century). In a number of cases, the platbands of church windows are decorated with serpentine figures. For instance, a round window on the south façade of the church in Akhtala (13 ${ }^{\text {th }}$ century) is surrounded with a wicker frame and then four serpents twisted by their tails. In the Church of Yeghegis ( $13^{\text {th }}$ century), the double roller platband ends with crossed snake heads, and the sundial just below the window once again confirms the solar symbolism of the images [15, p.55]. At the Jukhtak-vank's church (the end of the $12^{\text {th }}$ century), above the east window archivolt, two birds are carved with a double-headed short snake with wide-open mouths in between. Under the archivolt, just above the window, there is a schematic human face, presumably the sun allegory. An original composition of two dragons woven into a single body is depicted above the window edge in Nadarbazevi ( $10^{\text {th }}$ century), and the platband itself is also braided [2, p. 111, fig. 217]. The window as a source of light was itself associated with the sun, and the dragons in the above examples can be considered as the attributes of luminaries, and, at the same time, the guardians of the sacred space.

At the Nor-Varagavank monastery, the portal of the main church (1224-1237) is inlayed with multicolored and multi-shaped stone tiles, which have exquisite carvings of animals, plants, and geometric patterns. One of them presents two intricately intertwined dragons facing each other, whose bodies resemble a wicker ornament. On another tile, in the form of a four-pointed star, four pairs of snuggling dragon heads connected by a cruciform plexus can be distinguished. The same two dragons joined by their open jaws are carved inside the eight-pointed star on the altar elevation of the Vanstan church (Fig. 3-4). In the last examples, we have already seen a certain "ornamentation" of the dragon theme, its transformation into a braiding. And this is not at all to the detriment of the apotropaic symbolism of the dragon-snake, since the process of weaving itself and the braided ornament had protective functions from the ancient times. The intricate compositions drawn up from braiding motifs and dragon heads are often found in the decoration of Armenian manuscripts in a very close iconography with the sculptural samples $[15$, p. 54]. 


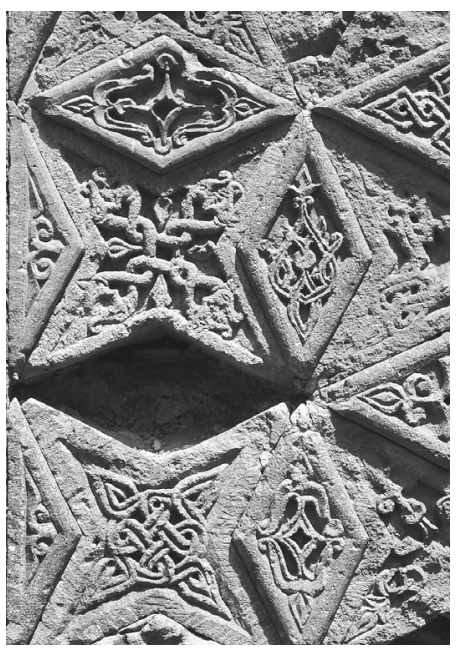

Fig. 3. Paired dragons' heads. Portal's tile. Nor-Varagavank church, Armenia. 1224-1237. Photo provided by Research on Armenian Architecture

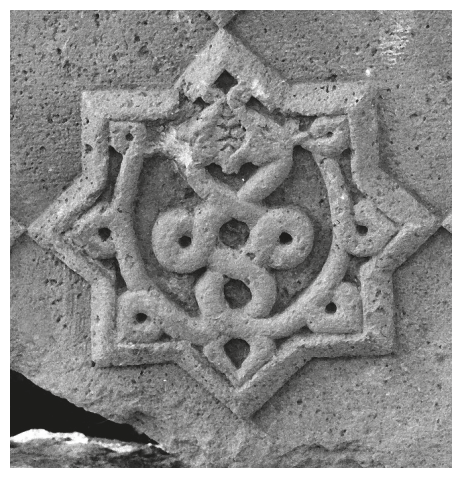

Fig. 4. Intertwined dragons. The front part of the bema, Vanstan church, Armenia. 1212-1227. Photo provided by Research on Armenian Architecture
On the sides of the main entrance of the Orbelian's (Selim) Caravanserai (1332), the reliefs of a bull and a sphinx are depicted. The tail of the sphinx is tied in a characteristic knot and terminating in a dragon head, which gaping mouth is turned towards the sphinx head. Considering the essential apotropaic meaning of these animals above the portal, they can be assumed to be the allegories of the sun and the moon. One should also take into account the solar symbolism of the sphinx in ancient mythologies, including the Urartian one, and the lunar symbolism of the bull. The latter is also recorded in the pictorial system of khachkars [22, fig. 267, 271]. Sphinxes with dragon tails are also found on the altar elevation of the church in Vanstan, on the portal of Nor-Varagavank, on the west façade of the church-tomb Burtelashen (1339) in Noravank. At the Geghard Monastery, in the rocky mausoleum of the $13^{\text {th }}$ century of the Proshyan princes, two forthcoming figures of lionesses with dragon tails are carved. These images were equally popular in the Near East art of the same period. Based on the well-known solar symbolism of sphinx and lion, their dragon tails can be considered as astral attributes, the symbols of the cyclicity of the luminaries. At the same time, the combination of several characteristic animal details in the image of fantastic creatures was supposed to enhance their artistic impact.

\section{Conclusion}

Since ancient times, the image of dragon-snake had ambivalent symbolism, which found vivid expressions in the art of the High Middle Ages. In the $6^{\text {th }}-7^{\text {th }}$ centuries, its depictions in Armenian and South Caucasian art represented mainly canonical images of this creature as the embodiment of the devil. This was due to the categorical denial by the early medieval Church of the pagan past and its images, and with that the benignant - the astral and apotropaic hypostasis of the dragon. After the Arab conquests, at the turn of the $9^{\text {th }}-10^{\text {th }}$ centuries, the process of rehabilitation of a number of archaic images begins. As a result, in parallel with the canonical ones, the images of dragons appear reflecting pre-Christian mythological notions about this monster.

Two compositional schemes of the $10^{\text {th }}$ century in Tatev and Kars: dragons flanking the image of a face-luminary and dragons on the sides of a human head or figure are among the earliest samples not only in the context of the Armenian Middle Ages, but also in the art of the Islamic Near East, where these compositions showed a particular development in the $12^{\text {th }}-13^{\text {th }}$ 
centuries. The $10^{\text {th }}$-century relief of Pavnisi with a dragon swallowing a solar disk can be considered one of the earliest expressions of the astral symbolism of this creature in medieval art. The motif of intertwined dragons in Sanahin and Nadarbazevi are also ahead of subsequent classical examples of the dragon - apotropaia.

A certain commonality of dragon images and sea monsters (in a number of plots of ancient mythology and in scenes of the prophet Jonah) is explained by the presence of a single archetype of these animals, embodying the elemental forces of nature that swallow and vomit the luminaries, the heroes, and the prophet Jonah. Thus, both the dragon and the sea monster were also the creatures that ensure the transition to another world or another state, including through the killing of a dragon by a hero (later the theme of Christ and the saints as snakeslayers). Being a liminal, borderline creature, the dragon also separated different worlds: the sky from the earth, the sacred - inner space from the outer - dangerous. It is this archaic function of the dragon-snake that determined its images over the entrances and windows of Christian and Islamic monuments.

In the Armenian art of the $12^{\text {th }}-14^{\text {th }}$ centuries, images of dragon and other fantastic animals become especially popular revealing amazing iconographic and stylistic commonality with Islamic and Eastern Christian samples. The images of both "light" and "dark" dragons have similar iconography, but if we summarize the variants of compositional schemes, we can conclude that in its demonic aspect the dragon was usually depicted singly: The Fall, Baptism of Christ, Holy Warriors killing a snake, etc. As a benevolent creature, it was rendered in the form of paired, heraldic dragons, sometimes flanking - i.e., guarding the central object.

\section{References}

1. Bobokhyan A.; Gilibert A.; Hnila P. Archaeology of Vishap Stones. The Vishap Stone Stelae. Yerevan, Gitutyun Publ., 2015, pp. 269-396 (in Armenian).

2. Dadiani T.; Khundadze T.; Kvachatadze E. Medieval Georgian Sculpture. Tbilisi, Cezanne Printing House Publ., 2017. 375 p.

3. Daneshvari A. Of Serpents and Dragons in Islamic Art. An Iconographical Study. Costa Mesa, Mazda Publ., 2011.238 p.

4. Der Nersessian S. Aght'amar. Church of the Holy Cross. Cambridge, Harvard University Press Publ., 1965. $132 \mathrm{p}$.

5. Endoltseva E. Arkhitekturnaia plastika Abkhazii v period Abkhazskogo tsarstva (VIII-XI vv.). Moscow, Institute of Oriental Studies Publ., 2020. 432 p. (in Russian).

6. Garsoian N. (transl. and comm.). The Epic Histories Attributed to P'awstos Buzand (Buzandaran Patmut 'iwnk'). Cambridge, Harvard University Press Publ., 1989. 665 p.

7. Ghafadaryan K. Dvin qaghaqy' ev nra peghumnery' II (The City of Dvin and its Excavations II). Yerevan, Academy of Sciences of Armenian Soviet Socialist Republic Publ., 1982. 166 p. (in Armenian).

8. Hakobyan Z. Masks in Medieval Armenian Sculpture. Actual Problems of Theory and History of Art, vol.5. St. Petersburg, NP-Print Publ., pp. 263-269 (in Russian). DOI: 10.18688/aa155-2-26

9. Hayrapetyan T. Combination of Archetypes in Armenian Tales of Magic and Epic Heritage. Yerevan, Gitutyun Publ. 2016. 462 p. (in Armenian).

10. Hovhannisyan K. Manifestation of the Archetypal Image of Dragon in the Armenian Worldview. Vishap on the Borderline of Fairy Tale and Reality. Yerevan, Institute of Archaeology and Ethnography Publ., 2019, pp. 75-105 (in Armenian).

11. Iamanidzé N. Saints cavaliers: Culte et images en Géorgie aux IVe-XIe siècles. Wiesbaden, Reichert Verlag Publ., 2016. 204 p. (in French). 
12. Israelian A. The Good Practices of Snakes and Dragons in the Armenian Beliefs. Vishap on the Borderline of Fairy Tale and Reality. Yerevan, Institute of Archaeology and Ethnography Publ., 2019, pp. 190-205 (in Armenian).

13. Kuehn S. Dragon in Medieval East Christian and Islamic Art. Leiden; Boston, Brill Publ., 2011. 298 p.

14. Kuehn S. The Dragon in Transcultural Skies: Its Celestial Aspect in the Medieval Islamic World. Spirits in Transcultural Skies. Auspicious and Protective Spirits in Artefacts and Architecture between East and West. Switzerland, Cham, Springer International Publ., 2015, pp.71-97.

15. Kyurkchyan A.; Khatcherian H. Armenian Ornamental Art. Yerevan, Craftology Publ., 2010. 190 p.

16. Mathews Th. Genesis Frescoes of Altamar. Revue des Études Arméniennes, 1982, vol. 16, pp. 245-257.

17. Mathews Th. Icons in Early Armenia and the Triptych of Dvin. FILOPATION. Sparziergang im Kaiserlichen Garten. Schriften über Byzanz und seinen Nachbarn. Festschrift für Arne Effenberger zum 70. Geburststag. Mainz, Romisch-Germanisches Zentralmuseum Publ., 2012, pp. 207-216.

18. Mikayelyan L. The Iconography of the Scenes of the Story of Jonah at the Church of the Holy Cross of Aghtamar. Early Christian, Jewish, Sasanian Sources and the New Interpretations. Vem Pan-Armenian Journal, 2018, no. 3 (63), pp. 182-204 (in Armenian).

19. Mikayelyan L. To the Interpretation of the Image of the So-called "Senmurv" according to the Armenian and Eastern Christian Monuments (VII-XIII). Transactions of the State Hermitage Museum, vol. 99. St. Petersburg, The State Hermitage Museum Publ., 2019, pp. 159-169 (in Russian).

20. Mnatsakanian St. Haykakan ashxarhik patkeraqandaky' IX-XIV darerum (Armenian Secular Relief of $11^{\text {th }}$ $14^{\text {th }}$ Centuries). Yerevan, Academy of Sciences of the Armenian Soviet Socialist Republic Publ., 1976. 177 p. (in Armenian).

21. Öney G. Sun and Moon Rosettes in the Shape of Human Heads in Anatolian Seljuk Architecture. Anatolica, 1969-1970, no. 3, pp. 195-209.

22. Petrosyan H. Khachkar: The Origins, Functions, Iconography, Semantics. Yerevan, Printinfo Publ., 2008. 406 p. (in Armenian).

23. Riccioni S. Dal kētos al sēnmurv? Mutazioni iconografiche e transizioni simboliche del kētos dall'Antichità al Medioevo (secolo XIII). Hortus Artium Medievalium, 2016, vol.22, 2016, pp. 130-144 (in Italian).

24. Thomson R. (transl. and comm.) Thomas Artsruni and Anonymous, History of the House of the Artsrunik. Detroit, Wayne State University Press Publ., 1985. 416 p.

25. Thomson R. (transl. and comm.). Moses Khorenats 'i: History of the Armenians. Ann Arbor, Caravan books Publ., 2006. 412 p.

Title. Various Aspects of the Image of a Dragon-serpent in Armenian and South-Caucasian Sculpture of the $7^{\text {th }}-14^{\text {th }}$ Centuries

Author. Mikayelyan, Lilit Shavarsh - researcher. Yerevan State University, Alex Manoogian St. 1, Yerevan 0025, Armenia.mikalil@mail.ru ORCID: 0000-0001-8766-2872

Abstract. In the Christian iconography, the image of dragon-snake is a well-known symbol of the devil and underworld. Its earliest images in the medieval sculpture of Armenia and South Caucasus are found on the $6^{\text {th }}-7^{\text {th }}$-centuries reliefs with holy warriors slaying a dragon. In the High Middle Ages, the snake was also depicted in the canonical scenes of the Fall, the Baptism of Christ, the Descent into Hell. However, since the $10^{\text {th }}$ century, other compositions appear on the church decoration reflecting the archaic notions of this creature - its benevolent functions. For instance for many peoples, the celestial serpent was thought to encircle the firmament, to delimitate it from the earth. It was also associated with the sun and moon cycles, the luminaries being periodically swallowed and erupted by the dragon. In this respect, the latter was fairly close to the sea monsters, in particular to the image of the whale of the prophet Jonah that determined their similar iconography. Heraldic compositions of the $10^{\text {th }}$ century with dragons flanking the human face reflect the astral symbolism of the monster. As a liminal creature, the dragon-serpent had the apotropaic functions. Therefore paired dragons were represented in a number of reliefs of the $12^{\text {th }}-14^{\text {th }}$ centuries on towers, church doorways and windows. They were usually rendered with wide-open jaws and intertwined bodies. This iconography has obvious parallels with the simultaneous Islamic examples of dragons having the same astral-apotropaic meaning.

Keywords: dragon, snake, Armenia, medieval art, relief, luminaries, apotropaic, symbolism 
Название статьи. Различные аспекты образа дракона-змея в пластике Армении и Южного Кавказа VII-XIV веков ${ }^{4}$

Сведения об авторе. Микаелян Лилит Шаваршевна - научный сотрудник. Ереванский государственный университет. Армения, Ереван 0025, ул. Алека Манукяна 1. mikalil@mail.ru ORCID: 0000-0001$8766-2872$

Аннотация. В христианской иконографии образ дракона-змея широко известен как символ дьявола и преисподней. Самые ранние его изображения в средневековой скульптуре Армении и Южного Кавказа встречаются в VI-VII вв. в сценах со святыми воинами, убивающими дракона. В период развитого средневековья змея появляется также в каноничных сценах Грехопадния, Крещения Христа, Сошествия в Ад. Однако с X в. в церковной пластике появляются композиции, отражающие архаичные представления об этом монстре - его благие функции. Так, у многих народов небесный змей мыслился окаймляющим небосвод, разделяющим небо и землю. Он также был связан с циклами солнца и луны, которые периодически поглощались и извергались драконом. В этом отношении образ последнего был весьма близок с морскими чудовищами, в частности с образом кита пророка Ионы, что определило близость их иконографии. В геральдических композициях начала Х в. с драконами и человеческим ликом в центре отразилась астральная символика монстра. Как пороговое существо, змей-дракон имел функции апотропея, что видно на целом ряде рельефов XII-XIV вв. с парными драконами на башнях, дверных проемах и окнах церквей. В последних драконы, как правило, изображались с раскрытыми ртами и переплетёнными телами. Данная иконография имеет очевидные параллели с исламскими образами драконов того же времени, имеющими одинаковую астрально-апотропеическую символику.

Ключевые слова: дракон, змей, Армения, средневековое искусство, рельеф, светила, апотропей, символика

4 Исследование проводилось в рамках гранта по проекту «Скульптурное убранство руинированных и мало изученных церковных комплексов Армении XII-XIV вв.» (21T-6E291), предоставленного Комитетом по науке при министерстве образования, науки, культуры и спорта Республики Армения. 


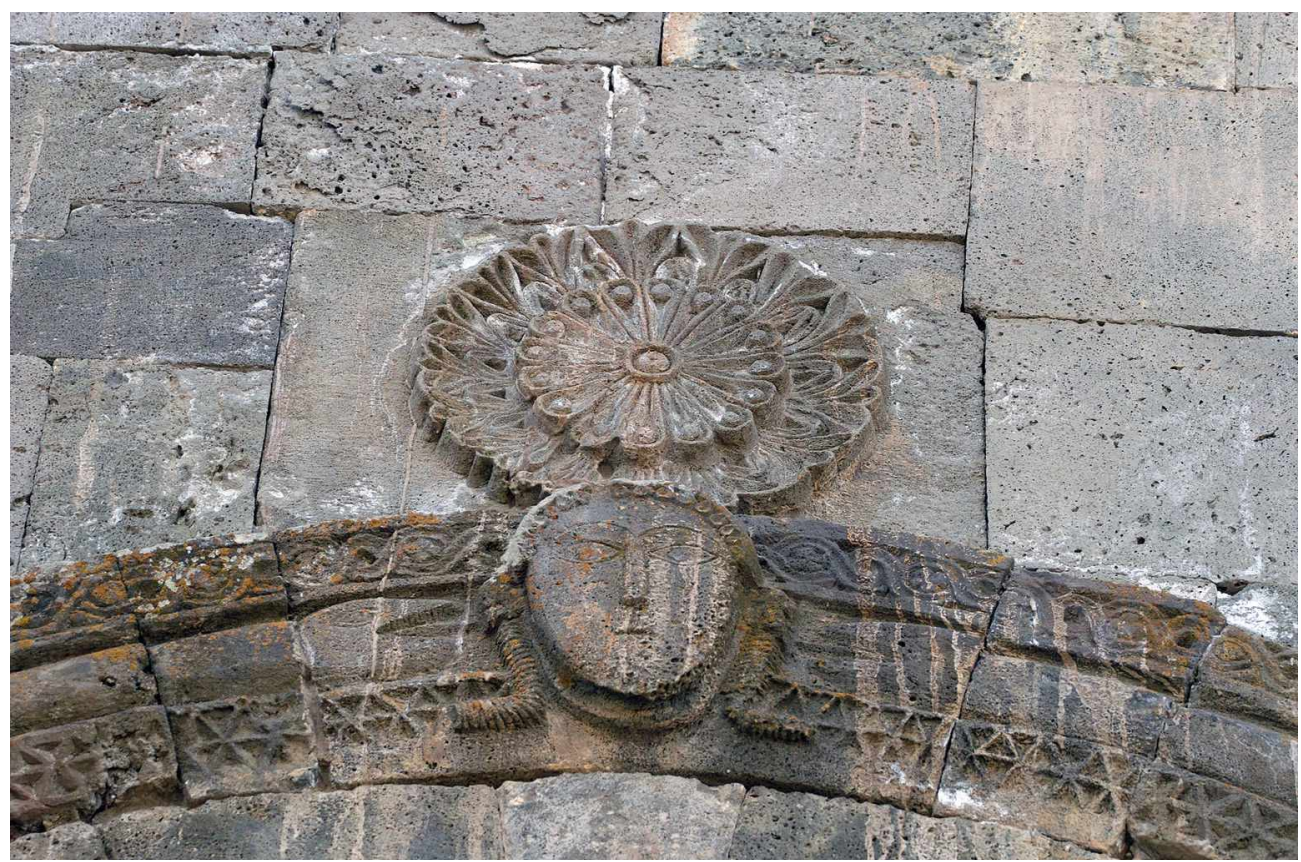

Ill. 21. Snakes flanking a human face. Eastern façade of Peter and Paul church, Tatev monastery, Armenia. 895-906. Photo by L. Mikayelyan

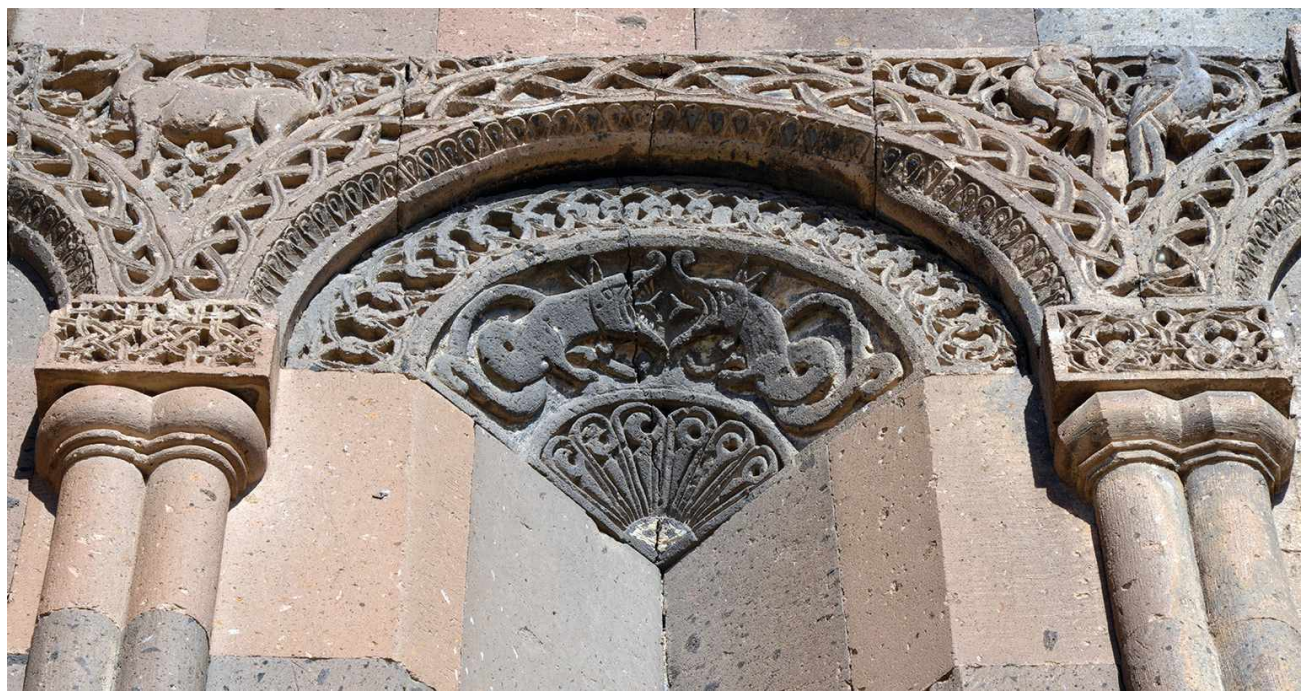

Ill. 22. Dragons. South façade of the church of St. Gregory (Tigran Honents). Ani, Historical Armenia, present-day Turkey. 1215. Photo by D. Grigoryan 